Andrzej Kacprzak (i) https://orcid.org/0000-0002-5474-2662

Iwona Kudlińska-Chróścicka (i) https://orcid.org/0000-0002-1277-2695

Uniwersytet Łódzki

\title{
MIĘDZY PRACA SOCJALNĄ A RESOCJALIZACJĄ. UWARUNKOWANIA PRACY SOCJALNEJ Z (BYŁYMI) WIĘŹNIAMI W POLSCE
}

\begin{abstract}
Between social work and social rehabilitation. Conditions of social work with ex-prisoners in Poland
\end{abstract}

People leaving penitentiary institutions, being at particular risk of social marginalization, are one of the target groups of social policy in the countries of the European Union. Social work with this social category, however, runs at the intersection of social policy and criminal policy, between which a distinct "fracture" has been observed in Poland for years. Collaboration of penitentiary units with social assistance institutions is usually of a small range, and the support offered to former prisoners in the return to society is "blurred" between systems (justice, penitentiary, social welfare) and their institutions. As one of the consequences, the social rehabilitation system does not benefit from social work's achievements.

The aim of the article is to outline the systemic context of Polish social work with people leaving penitentiary institutions and to draw attention to the possibility of using social work more widely than presently, in order to limit social marginalization of this social category and - from the point of view of criminal and penal policy - to reduce criminal recidivism.

Key words: social work, prisoners, rehabilitation, social policy, criminal policy, social exclusion, social reintegration

\section{Byli więźniowie jako podmiot pomocy społecznej w Polsce}

Stanowiąca podstawowy dokument sankcjonujący prowadzenie pracy socjalnej w Polsce - Ustawa o pomocy społecznej z dnia 1 stycznia 2004 roku - wymienia trudności w przystosowaniu do życia w społeczeństwie po zwolnieniu z zakładu karnego wśród okoliczności uprawniających do korzystania z usług pomocy społecznej (art. 7). Byli więźniowie są również wskazywani jako kategoria szczególnie zagrożona wykluczeniem społecznym w krajowych i lokalnych dokumentach strategicznych (np. w Zrewidowanej 
Strategii Spójności Społecznej z 2004 roku czy w Strategii Rozwoju Województwa Łódzkiego 2020). Problematyka pomocy społecznej byłym więźniom wpisuje się jednocześnie w ramy priorytetowych działań polityki inkluzyjnej Unii Europejskiej.

W Polsce więzienia co roku opuszcza ponad 45 tys. osób (zob. Roczna informacja statystyczna za rok 2018 2019: 15-16). Dane GUS i MRPiPS wskazują, że do instytucji pomocy społecznej dociera przynajmniej $30 \% \mathrm{z}$ nich. Możliwości prowadzenia pracy socjalnej z byłymi więźniami, choć mają swe ramy prawne i instytucjonalne, są jednak w Polsce dość poważnie ograniczone.

Byli więźniowie są podmiotem polityki społecznej stosunkowo od niedawna. Jako kategoria naznaczona piętnem społecznej dewiacji (za którą w społecznej percepcji może przemawiać zarówno sam fakt wejścia w konflikt z prawem, jak i skrajna forma odbytej kary w postaci izolacji od społeczeństwa) są stosunkowo mało popularną grupą docelową działalności pomocowej. W optyce społecznego audytorium byli więźniowie (obok takich kategorii społecznych, jak na przykład osoby bezrobotne, biedne, uzależnione, nastoletni rodzice czy rodziny wielodzietne) jawią się jako przynajmniej w pewnym stopniu odpowiedzialni za swoje wybory życiowe i swą sytuację, zwłaszcza w porównaniu z klientami tak zwanymi zależnymi (na przykład zaniedbywane dzieci, osoby przewlekle chore, osoby z niepełnosprawnością, samotni seniorzy). Stąd bywają oceniani jako grupa niezasługująca na objęcie systemem pomocy społecznej (zob. na przykład Raport z badań jakościowych... 2010).

Utrata wolności jest jednak w samych założeniach sytuacją wykluczenia społecznego (Lenczewska-Machel, Machel 2009: 218; Bradley 2005: 429; zob. też Zrewidowana Strategia Spójności Społecznej 2004). Trafiając do więzienia, skazany zostaje pozbawiony dostępu do ważnych zasobów, dóbr, aktywności, możliwości zaspokajania potrzeb (Rzecznik Praw Obywatelskich 2017: 68; szerzej: Miszewski 2015: 21-22; Chmielewska 2004: 165-171; Sykes 1958, za: Ciosek 2003: 299-300). Ze struktury codziennych czynności znikają role społeczne, które skazany pełnił, przebywając na wolności, na przykład partnera, rodzica, członka społeczności lokalnej, pracownika, konsumenta dóbr, by wymienić tylko te najbardziej podstawowe (zob. Żelazek 2003: 74). Jak wskazuje Jenny Phillips (2001: 14), zachodzi wówczas proces równoważenia statusów między osadzonymi - wszyscy podlegają tym samym prawom i obowiązkom, tej samej zrutynizowanej i odgórnie nakreślonej codzienności, mają dostęp do tych samych zasobów, obejmują ich te same ograniczenia itd. (zob. Goffman 2011; 1975). Większość badaczy idzie jednak o krok dalej, zauważając, że pobyt w więzieniu pociąga za sobą najczęściej wielowymiarową degradację skazanego: psychologiczną, społeczną, ekonomiczną (Goffman 2011: 24; 1975: 8; zob. też: Hołda i in. 2017: 115; Poklek 2010: 44; Przybyliński 2005: 69). Utrata wolności przez człowieka uderza w fundamenty jego obrazu siebie jako (pełno)wartościowego członka zbiorowości. Poprzez działania wymiaru sprawiedliwości społeczeństwo izoluje go od reszty obywateli, dając mu niejako do zrozumienia, że nie jest już jego integralną częścią (por. Uggen i in. 2011).

Wiele badań polskich (na przykład Sytuacja osób opuszczających zakłady karne na terenie województwa łódzkiego 2012; Fidelus 2012; Kieszkowska 2012; Szymanowska 
2003) i zagranicznych (na przykład Visher 2015; Western, Pettit 2010; Baldry i in. 2006; Houchin 2005; Nelson i in. 1999) dowodzi, że problemy w ponownym funkcjonowaniu w społeczeństwie są wśród byłych więźniów powszechne. Osoby opuszczające zakłady karne najczęściej nie mają własnych dochodów bądź są one niewielkie. Posiadane przez nich środki też są najczęściej dosyć skromne. Na etapie pobytu w polskim więzieniu pracuje tylko nieco ponad połowa skazanych - większość z tej grupy zaś wykonuje prace nieodpłatne. Dla tych, którzy pracują odpłatnie, średnie miesięczne wynagrodzenie wynosi nieco ponad $1450 \mathrm{zł}$ (zob. Roczna informacja statystyczna za rok 2018 2019: 25-30). Z kolei na wolności byli więźniowie napotykają liczne bariery w podjęciu pracy. Są one z jednej strony związane z małą atrakcyjnością rynkową osób karanych, legitymujących się zazwyczaj niskim poziomem wykształcenia i kwalifikacji zawodowych (Fidelus 2012; Social Exlusion Unit 2002). Byli więźniowie to nieraz także osoby, które utraciły nawyk pracy w trakcie odbywania kary, niektórzy obawiają się jej podjęcia, a nawet poszukiwań, ponieważ nigdy wcześniej nie pracowali. Z drugiej strony trudności byłych więźniów na rynku pracy są wzmacniane przez moralne postawy społeczeństwa wobec osób z kryminalną przeszłością, w tym zwłaszcza ich negatywne postrzeganie przez pracodawców. Warto nadmienić, że ta ostatnia bariera jest wzmacniana także przez rozwiązanie systemowe w postaci Krajowego Rejestru Karnego, w którym figurują personalia skazanych.

Problemy materialne byłych więźniów dotyczą nie tylko ich niewielkich zasobów finansowych, lecz także sytuacji mieszkaniowej. Różne badania wskazują, że około $40 \%$ populacji bezdomnych stanowią osoby, które przynajmniej raz w życiu przebywały w więzieniu (Piechowicz 2012; Olech 2010: 200; szerzej: Kacprzak 2017), przy czym część $\mathrm{z}$ nich, zwłaszcza w okresie zimowym, trafia do zakładów karnych umyślnie, przewidując lepsze warunki bytowe niż na wolności. Zagrożenie bezdomnością jest szczególnie wysokie w sytuacji braku wsparcia rodziny (Visher 2015). Analizy Aleksandry Szymanowskiej (2009) wskazują, że wraz z zaawansowanym wiekiem, czasem spędzonym w więzieniu i liczbą odbywanych wyroków zmieniają się zasadniczo możliwości korzystania przez byłych skazanych z nieformalnych źródeł wsparcia. O ile stosunkowo młodzi skazani, wychodząc na wolność, oczekują w pierwszej kolejności wsparcia rodziny pochodzenia lub prokreacji, o tyle stanowiący ponad połowę populacji więziennej recydywiści (zob. Roczna informacja statystyczna za rok 2018 2019: 7) najczęściej nie mają takiej możliwości, ze względu na zerwanie kontaktów z rodziną, zaawansowany wiek lub śmierć rodziców bądź też dlatego, że zasoby ich bliskich są również niewielkie. Marta Nelson i inni (1999: 19) wskazują, że grupa ta doświadcza silniejszych napięć w sytuacjach niepowodzeń, szybciej zniechęca się na przykład do poszukiwania pracy, rezygnuje z udziału w kursach i szkoleniach, częściej przerywa leczenie uzależnień i wraca do nałogu (zob. też Haney 2003: 47). Z kolei Thomas Mowen i Christy Visher (2013: 12-14) dowodzą, że byli więźniowie skonfliktowani z rodziną częściej wracają do zakładów karnych. Wobec braku wsparcia bliskich stają się zależni od zasobów tak zwanej pomocy postpenitencjarnej. Obejmuje ona wsparcie instytucji publicznych (sądów i ośrodków pomocy społecznej) oraz organizacji pozarządowych 
oferujących pomoc byłym skazanym. Wsparcie finansowe tych pierwszych ma jednak najczęściej charakter raczej symboliczny: oprócz niewysokiego zasiłku bywają to bony żywnościowe, środki na zakup biletu, używana odzież. Z kolei NGOsy specjalizują się zwykle w innych formach pomocy, nie oferując finansowej, na którą liczy znaczna część opuszczających więzienia, w tym większość recydywistów (zob. Szymanowska, Korwin-Szymanowski 2009). W tych okolicznościach byli więźniowie niejednokrotnie decydują się na powrót do przestępczości.

Liczni badacze wskazują, że osoby uzależnione doświadczają szczególnych trudności w przystosowaniu do życia na wolności po opuszczeniu zakładu karnego: rzadziej znajdują pracę lub częściej ją tracą, częściej są bezdomni (Moore i in. 2016: 13; Mowen, Visher 2013; Kinner 2006: 30-34; Travis i in. 2001). Częściej także powracają do zakładów karnych (zob. Bronson i in. 2017; Mumola, Karberg 2006; Mumola 1999). Według polskich badań przynajmniej $40 \%$ populacji więziennej to osoby z problemem alkoholowym (Szymanowska 2003: 148-149), a liczba skazanych uzależnionych od narkotyków od lat systematycznie rośnie (zob. na przykład Motyka 2013: 439). Odsetek uzależnionych wśród skazanych jest przy tym wielokrotnie wyższy niż w populacji ogólnej (Europejskie Centrum Monitorowania Narkotyków i Narkomanii 2017: 69; Social Exclusion Unit 2002: 62). Niepokojący jest wobec tego brak profesjonalnego wsparcia w okresie odbywania kary. Oddziaływania terapeutyczne w zakładach karnych obejmują tylko niewielki odsetek skazanych - w latach 2002-2018 nigdy nie przekroczył progu 5\% (obliczenia własne na podstawie Roczna informacja statystyczna za rok 2018 2019: 32). W 2015 roku Najwyższa Izba Kontroli bardzo krytycznie oceniła dostępność penitencjarnych oddziałów terapeutycznych, wskazując, że rzeczywiste zapotrzebowanie jest zdecydowanie większe. Świadczy o tym długi czas oczekiwania na przyjęcie na oddział terapeutyczny, wynoszący odpowiednio ponad 14 i 12 miesięcy dla więźniów z problemem alkoholowym i uzależnionych od innych substancji odurzających (Najwyższa Izba Kontroli 2015: 38-39). Brak działań wspierających w tym zakresie na etapie pobytu w więzieniu, okresie sprzyjającym - jak się wydaje - wszelkim aktywnościom skazanych, które zmniejszą ryzyko recydywy, wyraźnie koliduje z interesem społecznym. Łączy się zazwyczaj (por. Klingemann 2012) z brakiem gotowości, by zerwać z nałogiem i jego prawdopodobnym powrotem do uzależnienia po wyjściu na wolność.

Omówione bariery mają tendencję do kumulacji w przebiegu życia skazanych: trudności doświadczane w jednej sferze życia współwarunkują problemy w innych. Wpisują się tym samym w definicję współczesnych procesów wykluczania społecznego. Należy przy tym podkreślić, że w wielu przypadkach okoliczności te, lokujące (byłych) skazanych wśród „wykluczonych”, wyprzedzają de facto pierwszy wyrok pozbawienia wolności. W porównaniu z populacją ogólną skazani to osoby znacznie częściej rekrutujące się ze środowisk spauperyzowanych, rodzin dysfunkcyjnych, o zaburzonej strukturze i dynamice wewnętrznej oraz niskim statusie społecznym, doświadczające trudności na rynku pracy, uzależnione czy bezdomne (zob. na przykład The vicious circle... 2012; Houchin 2005; Szymanowska 2003; Social Exclusion Unit 2002). Większość kryminologów nie ma jednak wątpliwości, że pobyt w więzieniu szczególnie przyczynia się do pogłębiania 
deficytów skazanych. Dlatego też w ostatnich latach coraz częściej zwracają uwagę na to, że więzienie w większym stopniu produkuje przestępczość niż jej przeciwdziała (Sampson 2011, za: Morenoff, Harding 2014: 7). W tych warunkach cel kary pozbawienia wolności, jakim jest przywrócenie osoby skazanej społeczeństwu (por. Jaworska 2012: 79-80), jest rozbieżny z jej rzeczywistymi rezultatami, ponieważ wykluczenie społeczne tworzy sytuacje o charakterze kryminogennym, zarówno pośrednio (zob. Reiman 2001), jak i bezpośrednio (zob. Hołyst 2007).

W świetle wskazanych barier reintegracji społecznej praca socjalna $z$ osobami opuszczającymi instytucje karne wydaje się szczególnie uzasadniona. Czy i na ile jednak uwarunkowania systemowe tworzą w Polsce kontekst sprzyjający pracy socjalnej $\mathrm{z}$ tą kategorią? W dalszej części tekstu przyjrzymy się, jak wygląda proces przywracania skazanych społeczeństwu i spróbujemy określić, gdzie w tym procesie znajduje się miejsce dla pomocy społecznej i pracy socjalnej.

\section{Pomoc społeczna w kontekście polskiej polityki karnej}

Profesjonalna praca socjalna, której adresatem są byli skazani, funkcjonuje na przecięciu polityki społecznej i polityki karnej. Skrzyżowanie ich celów, choć z pozoru korzystne, wytwarza w Polsce wiele systemowych i instytucjonalnych barier, poważnie ograniczających efektywność pracy socjalnej z tą kategorią klientów. Należy tutaj zaznaczyć, że Polska jest jednym z nielicznych krajów Unii Europejskiej realizujących model tak zwanej punitywnej (to jest represyjnej) polityki karnej. Świadczą o tym liczne przesłanki.

Po pierwsze, karą najczęściej stosowaną przez polskie sądy jest pozbawienie wolności (bezwzględne lub w zawieszeniu). Mimo że sam Kodeks karny jest uznawany za dosyć liberalny, kary nieizolacyjne (grzywna samoistna, ograniczenie wolności) są stosowane relatywnie rzadko, natomiast propozycje wprowadzania alternatywnych form resocjalizacji w środowisku otwartym, jak probacja czy sprawiedliwość naprawcza, pozostają tylko postulatami (zob. Filar 2014: 52; Bałandynowicz 2008: 216). Polska jest krajem przodującym w Unii Europejskiej pod względem liczby osadzonych (5. najwyższy wskaźnik liczby osadzonych przypadających na 100 tys. mieszkańców i 2. największa populacja osadzonych w liczbach bezwzględnych ${ }^{1}$ ). Tendencja ta utrzymuje się niezależnie od stale malejących wskaźników przestępczości i w oderwaniu od faktu, że Polska należy do krajów stosunkowo bezpiecznych (szerzej: Kacprzak 2016). Do polskich zakładów karnych regularnie trafiają między innymi sprawcy drobnych kradzieży, posiadacze niewielkich ilości narkotyków, a także tak zwani przestępcy incydentalni, na przykład dłużnicy alimentacyjni czy sprawcy przestępstw drogowych (do 2015 roku również tak zwani pijani rowerzyści), których potrzeba i sens resocjalizacji bywają kwestionowane (zob. na przykład Stępniak 2017). Środowisko więzienne może się bardziej przyczyniać do ich demoralizacji niż ich resocjalizować. Nie jest jasne, na

\footnotetext{
${ }^{1}$ Dostęp do danych: http://www.prisonstudies.org/map/europe (dostęp: 15.02.2019).
} 
ile i w jaki sposób kara pozbawienia wolności ma prowadzić do readaptacji społecznej skazanych, zwłaszcza niektórych specyficznych grup spośród nich. Przyjmuje się, że okresem, w którym praca resocjalizacyjna ma szansę osiągnąć pożądany poziom efektywności, jest 5 lat. Tymczasem większość skazanych trafia do zakładów karnych $\mathrm{z}$ wyrokami nieprzekraczającymi 3 lat pozbawienia wolności. Na przeciwległym biegunie lokują się osoby wychodzące na wolność po wyrokach wieloletnich (15 lat i więcej), które do warunków placówki są przystosowane znacznie lepiej niż do funkcjonowania na wolności (szerzej: Stępniak 2017).

Po wtóre, proponowane przez Ministerstwo Sprawiedliwości zmiany w Kodeksie karnym wpisują się w charakterystyczny dla państw neoliberalnych dyskurs represyjny, skoncentrowany wokół doktryny „zero tolerancji” (Wacquant 2009: Wstęp do wydania polskiego). Zjawisko to, określane w literaturze przedmiotu jako „penalny populizm”, polega na surowym karaniu „najbardziej uciążliwej” przestępczości ulicznej (w rzeczywistości mniej szkodliwej społecznie niż na przykład przestępstwa gospodarcze), co prowadzi do dalszego wzrostu liczebności populacji więziennej (zob. na przykład Czapska i in. 2016).

Po trzecie, działania reintegracyjne są zlecane głównie podmiotom niepublicznym w formie konkursów. Ciężar odpowiedzialności za ponowne włączanie skazanych do społeczeństwa spoczywa zatem na organizacjach pozarządowych. Państwo pełni natomiast jedynie rolę pośrednika, czego jedną z konsekwencji jest brak działań systemowych na rzecz opuszczających więzienia. System resocjalizacyjny w nieznacznym stopniu współpracuje z systemem pomocy społecznej - najlepszym tego dowodem jest brak pracowników socjalnych zatrudnionych w polskich więzieniach oraz brak systemowych powiązań organizacyjnych, logistycznych, technicznych między instytucjami karnymi a pomocowymi. Koncentracja państwa na realizacji kary, z pominięciem działań wspierających, świadczy o większym zainteresowaniu realizacją jej funkcji retrybutywnej kosztem funkcji korekcyjnej (por. Kornblum, Julian 2012: 169; Płatek 2007: 273; zob. też Frieske, Poławski 1996: 15-39).

Podnoszona od lat kwestia ograniczeń systemu resocjalizacyjnego w Polsce nie stanowi, jak dotąd, bodźca do wprowadzania zmian w zakresie współpracy międzyinstytucjonalnej na linii system penitencjarny-system pomocy społecznej. Bezpośrednimi aktami prawnymi sankcjonującymi kwestie współpracy między nimi są: Kodeks karny wykonawczy oraz Ustawa o pomocy społecznej i (w węższym zakresie) Ustawa o Służbie Więziennej. Współpracę między administracją więzienną a instytucjami pomocy społecznej w związku z przeciwdziałaniem pogłębianiu („się") zjawiska wykluczenia społecznego osób skazanych i ich rodzin reguluje również Porozumienie zawarte pomiędzy Ministerstwem Pracy i Polityki Społecznej a Centralnym Zarządem Służby Więziennej z dnia 13 czerwca 2000 roku. Jego strony zobowiązały się wówczas do współdziałania w zakresie:

- utrzymywania więzi między skazanymi a ich rodzinami;

- monitorowania zdolności i zakresu realizacji obowiązku alimentacyjnego przez skazanych zatrudnionych; 
- udzielania pomocy w kierowaniu skazanych opuszczających zakłady karne do środowiskowych grup wsparcia lub ośrodków wsparcia (w przypadku więźniów odbywających karę w systemie terapeutycznym);

- udzielania pomocy w kierowaniu skazanych, u których stwierdzono uzależnienie od alkoholu, środków odurzających lub psychotropowych, na leczenie odwykowe;

- rozwiązywania problemów życiowych skazanych i ich rodzin, a zwłaszcza do poprawy trudnej sytuacji materialnej $(\$ 2)$.

Cytowane porozumienie nie obejmuje, niestety, najważniejszych - naszym zdaniem zagadnień. Nie określa bowiem, w jakiej formie owa współpraca ma przebiegać, na czym ma polegać, jakie są kompetencje i obowiązki obu stron, ani też nie obejmuje swoim zakresem czasu wykonywania kary. Zgodnie z treścią porozumienia działalność instytucji pomocy społecznej w okresie odbywania kary pozbawienia wolności ogranicza się do rodziny skazanego, przy czym może ona zostać objęta pomocą społeczną jedynie na wniosek jej członków lub samego skazanego. Skazany może natomiast zgłosić prośbę o wsparcie w placówce pomocy społecznej po opuszczeniu placówki (art. 3 pkt 1). Oznacza to, że współpraca instytucji penitencjarnych z instytucjami pomocy społecznej ma conditio iuris charakter cząstkowy i zależy od tego, jak władze danego zakładu karnego oceniają potencjalną „przydatność” pomocy społecznej do realizacji zadań placówki.

W praktyce owa współpraca ogranicza się zazwyczaj do udzielenia osobie opuszczającej więzienie informacji o możliwości zgłoszenia się do ośrodka pomocy społecznej w celu uzyskania świadczeń z tytułu trudności w przystosowaniu do życia po opuszczeniu placówki. Świadczy to o braku zrozumienia istoty pracy socjalnej, utożsamianej niekiedy błędnie przez gorzej zorientowanych pedagogów resocjalizacyjnych (zob. na przykład Makowiecka 2008: 87-89) ze świadczeniami pieniężnymi. Pracy socjalnej $\mathrm{z}$ byłym skazanym nie należy też mylić z pomocą postpenitencjarną.

\section{Specyfika i metodyka pracy socjalnej z (byłymi) więźniami²}

Praca socjalna z (byłymi) skazanymi ma swoją specyfikę. Po pierwsze, jest prowadzona w osobliwym społecznym kontekście. Jak już sygnalizowaliśmy, w społecznej percepcji osoba, która przebywała w zakładzie karnym, to często jednostka zdemoralizowana, pomaganie jej jest zaś mało uzasadnione, ponieważ popełniając przestępstwo, zasłużyła na karę. Pracownik socjalny musi więc rezultatami swojej pracy udowadniać społecznemu audytorium sens pracy z klientem łamiącym normy społeczne. Po wtóre, praca z osobą karaną wymaga wiedzy i umiejętności z wielu dziedzin: socjologii, psychologii, kryminologii, pracy socjalnej, w tym dobrej znajomości prawa i wiedzy na temat barier

${ }^{2}$ Metodykę pracy socjalnej z byłymi więźniami szczegółowo opisujemy w książce: A. Kacprzak, I. Kudlińska (2014). Praca socjalna z osobami opuszczającymi placówki resocjalizacyjne i ich rodzinami. Centrum Rozwoju Zasobów Ludzkich, Warszawa. 
prawnych, z którymi spotykają się klienci (na przykład wymaganie przez pracodawców zaświadczenia o niekaralności). Po trzecie, jest prowadzona w przestrzeni między wieloma różnymi instytucjami rozmaitych systemów: sprawiedliwości, pomocy społecznej, edukacji, zdrowotnego itd. Pracownik socjalny musi dobrze orientować się w lokalnej i regionalnej bazie instytucji oferujących wsparcie (byłym) więźniom.

Praca socjalna z byłym więźniem jest niejednokrotnie pracą z klientem wieloproblemowym, doświadczającym trudności w różnych sferach życia, a często także -społecznej opresji i dyskryminacji. Ze względu na wielowymiarowość doświadczanych trudności $\mathrm{w}$ powrocie do społeczeństwa wymaga zrozumienia trajektorii biograficznej klienta, „wczucia się" w jego sytuację. Zadaniem pracownika socjalnego w pracy z byłym więźniem jest również podtrzymywanie (a niekiedy także wywołanie) w nim motywacji do osiągnięcia zamierzonej „zmiany”, wspieranie podejmowanych przez niego działań w kierunku przezwyciężania piętna dewianta, takich jak: podejmowanie pracy, realizacja ról rodzinnych, podjęcie leczenia z uzależnienia, uczestnictwo w spotkaniach grupy samopomocowej, unikanie destrukcyjnego towarzystwa, wolontariat $w$ organizacji pozarządowej. Sprzyja temu relacja zindywidualizowana, w profesjonalnej pracy socjalnej realizowana najpełniej $w$ ramach podejścia skoncentrowanego na osobie (person-centered approach social work). Model ten opiera się na czterech zasadach budowy relacji zaufania i wzajemnego szacunku między pracownikiem socjalnym a klientem:

1. Bezwarunkowy szacunek - traktowanie klienta jako równoprawnego partnera w relacji pomocowej, respektowanie jego opinii i poglądów niezależnie od własnych, by klient mógł swobodnie wyrażać swoje myśli, potrzeby, uczucia i oczekiwania.

2. Odrębność osoby - pracownik socjalny zachowuje niezależność uczuciową, nie dając się zdominować uczuciom klienta, ale też samemu nie może nad nim dominować i nie może narzucać własnych poglądów.

3. Autentyczność i zgodność z rzeczywistością - powinien w swoich relacjach z klientem być „prawdziwy”. Niezbędna jest świadomość własnych uczuć i komunikowanie ich drugiej stronie relacji.

4. Akceptacja - powinien być wolny od podejrzliwości wobec klienta, wierzyć w jego zdolność i chęć „zmiany”, unikać oceniania i osądzania klienta, starać się postrzegać go takim, jakim on sam się widzi, i starać się zrozumieć jego perspektywę (Beckett 2010: 82-85).

Praca socjalna $\mathrm{z}$ osobami karanymi to również niejednokrotnie praca $\mathrm{z}$ klientem biernym, niezmotywowanym, uskarżającym się na brak kontroli nad własnym życiem i bezradność wobec przytłaczających go trudności, doświadczającym społecznej opresji i dyskryminacji. W tym kontekście wysoką efektywność wykazuje praca socjalna skoncentrowana na rozwiązaniach. Poziom przestępczości powrotnej w realizujących ją grupach jest niższy niż wśród więźniów uczestniczących w innych formach terapii i znacząco niższy niż wśród skazanych nieuczestniczących w żadnych formach oddziaływań poza "standardową" resocjalizacją (zob. na przykład Newsome 2004; Milner, Jessop 2003; Lindforss, Magnusson1997). Podobne zastosowanie ma model zadaniowy, sprawdzający się zwłaszcza w pracy z klientem niedobrowolnym i przy ograniczonych 
ramach czasowych. Taka sytuacja ma miejsce na przykład wtedy, gdy skazany przebywa na warunkowym przedterminowym zwolnieniu lub został poddany probacji, a zatem funkcjonuje w ramach tak zwanej resocjalizacji w środowisku otwartym. Praca socjalna skoncentrowana na zadaniu ma metodyczny i etapowy charakter, w którym wyróżnia się następujące kroki: rozpoznawanie problemów, wyznaczenie priorytetowych problemów klienta, celu i ram czasowych, w których ma zostać zrealizowany, zaplanowanie zadań i ich realizacja oraz zakończenie zaangażowania, czyli zwykle po 3 miesiącach. Model ten jest nastawiony na szybkie rozwiązanie doświadczanych trudności.

Specyfika pracy socjalnej z osobami karanymi wynika również z innej charakterystyki klientów - są to nierzadko osoby zmagające się z problemami z zachowaniem: skonfliktowane $\mathrm{z}$ bliskimi, uzależnione od alkoholu lub/i narkotyków czy uwikłane w przemoc. Są to cechy klientów, z którymi skutecznym modelem pracy są terapie poznawczo-behawioralne (TPB). Terapie kognitywno-behawioralne obejmują zazwyczaj pracę z klientem w 3 sferach jego funkcjonowania: poznawczej, behawioralnej i emocjonalnej. $\mathrm{W}$ pracy socjalnej z (byłymi) skazanymi z powodzeniem możliwe jest wykorzystanie głównych zasad, według których przebiega proces kształtowania postaw prospołecznych:

1. jasne identyfikowanie prospołecznych twierdzeń i zachowań oraz ich nagradzanie poprzez okazywanie swojego uznania, aprobaty;

2. dawanie przykładu własnym zachowaniem, jakie działania i wartości są pożądane przez innych, a jakie mogą być dla nich krzywdzące;

3. asertywne sprzeciwianie się niestosownym stwierdzeniom i postawom klienta;

4. zachowanie czujności, by nie wzmacniać zachowań społecznie nieakceptowanych, zarówno przez werbalne komunikaty, jak i te niewerbalne (na przykład potakiwanie, uśmiech) (Trotter 1999: 17-23).

Efektywność TPB w redukowaniu przestępczości powrotnej szacuje się na 10-30\%, co jest wskaźnikiem relatywnie dobrym. Ich absolwenci częściej niż inni byli więźniowie podejmują zatrudnienie, kontynuują naukę, uzyskują niezależność finansową (Friednship i in. 2002).

Przeprowadzona ( $\mathrm{z}$ konieczności skrótowo) charakterystyka kategorii byłych więźniów w kontekście metodycznym wskazuje na przynajmniej kilka możliwości efektywnego wykorzystania pracy socjalnej w celu zmniejszenia ryzyka przestępczości powrotnej. Praca socjalna koncentruje się na działaniach wspierających umiejętność autonomicznego funkcjonowania, samopomocy, wykorzystywania lub wzmacniania materialnych i niematerialnych zasobów podmiotu pomocy (jednostki, grupy, środowiska) (Grabusińska 2012: 36). Uogólniony długofalowy cel działań na rzecz osoby opuszczającej więzienie, to jest adaptacja do życia w społeczeństwie, wydaje się zbieżny z paradygmatem resocjalizacyjnym. O ile jednak model resocjalizacyjny przyjmuje, że jest ona w zasadzie tożsama $\mathrm{z}$ brakiem recydywy, o tyle w paradygmacie pracy socjalnej brak powrotu do przestępczości jest jednym $\mathrm{z}$ niezbędnych kryteriów, by były skazany mógł w ogóle zafunkcjonować w społeczeństwie. Praca socjalna, poprzez tworzenie sprzyjających warunków życiowych i wspieranie byłego skazanego w realizacji jego legalnych działan, zmierza do stanu, który określa się jako integrację ze społeczeństwem. Brak recydywy 
jest jednym z jej wskaźników, ale nie jedynym. Są nimi również: zdolność do sprawnego funkcjonowania w środowisku i realizacji ról społecznych (zawodowej, rodzinnej, obywatelskiej, odpowiedzialnego konsumenta dóbr itd.), umiejętność projektowania i realizacji indywidualnych celów życiowych, niezależność ekonomiczna, życiowa, decyzyjna czy dostęp do zasobów i praw przysługujących wszystkim obywatelom. Istotą pracy socjalnej jest wspieranie klienta w osiągnięciu tego stanu. Służą temu świadomie i planowo podejmowane działania pomocowe, które powinny być realizowane $\mathrm{z}$ poszanowaniem niezależności klienta i jego prawa do samostanowienia. W przeciwieństwie do wertykalnego (relacja góra-dół) modelu resocjalizacji profesjonalna praca socjalna opiera się na relacji horyzontalnej, w której podmiot pomocy staje się aktywnym partnerem.

Istotą resocjalizacji jest bowiem zmiana osobowości przestępcy tak, by w przyszłości przyjmował postawy konformistyczne. Zakłada się, że na wcześniejszym etapie biografii przestępca został zsocjalizowany w sposób (ze społecznego punktu widzenia) niepoprawny, zatem wymaga działań korekcyjnych. Model resocjalizacji zakłada wywołanie "zmiany" poprzez zewnętrzną interwencję, to jest oddziaływania resocjalizacyjne, takie jak praca skazanego, edukacja, udział w terapii, zajęciach sportowych i kulturalno-oświatowych czy tak zwanych programach readaptacji społecznej. Dostępność tych oddziaływań w więzieniu jest jednak ograniczona, a ich jakość i celowość - mocno dyskusyjne (Najwyższa Izba Kontroli 2015). Oddziaływania resocjalizacyjne są z reguły silnie zestandaryzowane, przez co mają też niewielką zdolność i efektywność w wydobywaniu indywidualnych potencjałów skazanych. Warto przy tym zauważyć, że pobyt $\mathrm{w}$ więzieniu, czyli w izolacji od społeczeństwa, ma służyć przystosowaniu skazanych do życia w tymże społeczeństwie, podczas gdy de facto adaptuje do życia w zamkniętej placówce (Goffman 2011). Tym samym działania resocjalizacyjne, mające za zadanie aktywizować skazanych społecznie, edukacyjnie, zawodowo, przebiegają w kontekście wspierającym postawy bierności, bezradności społecznej czy tak zwanej roszczeniowości. Innymi słowy, paradygmat resocjalizacji izolującej składa się z elementów antytetycznych, redukujących efektywność owych oddziaływań.

\section{Więzienna praca socjalna}

Praca socjalna w placówkach resocjalizacyjnych dla dorosłych to rozwiązanie sprawdzone i stosowane od lat między innymi we Francji, Niemczech, Włoszech, Anglii czy krajach skandynawskich (Stępniak 2007; 1998). W Stanach Zjednoczonych praca socjalna z osadzonymi ma jeszcze dłuższe tradycje. Sięga początków poprzedniego stulecia. Jej wielkim rzecznikiem i propagatorem był Kenneth Pray, były dziekan Wyższej Szkoły Pracy Społecznej Uniwersytetu Pensylwanii (obecnie Szkoła Polityki Społecznej i Praktyki), który w latach czterdziestych pisał:

Poprzez kompetentne i współczujące zaangażowanie i wysiłki interwencyjne, które opierają się mocno na wartościach pracy socjalnej, pracownik socjalny może wnieść swój własny wkład 
w osiągnięcie celu więzienia, który jest poświęcony zarówno dobru więźnia, jak i ochronie wspólnoty (Pray 1943: 7, za: Matejkowski i in. 2016: 8).

Pomysł włączenia pracy socjalnej do systemu resocjalizacji przestępców nie spotkał się początkowo z ciepłym przyjęciem przez pomoc społeczną. Być może ze względu na to, że wartości, na których opiera się profesj, są w wielu punktach sprzeczne z paradygmatem resocjalizacji i samą instytucją kary pozbawienia wolności. Dopiero boom populacji więziennej od lat osiemdziesiątych XX wieku związany z realizacją (popularnej obecnie również w Polsce) polityki „zero tolerancji” oraz „wojny z przestępczością” (zob. Wacquant 2010; 2009) unaocznił potrzebę sięgnięcia przez instytucje penitencjarne po unikatowy zestaw umiejętności zawodowych pracowników socjalnych (Matejkowski i in. 2016: 8). Kompetencje z zakresu pracy socjalnej pojawiły się również wśród wymagań stawianych kuratorom sądowym. Pracownicy socjalni są na terenie zakładów karnych zatrudniani, by wspierać skazanych w organizacji zasobów i przygotować ich do samodzielnego (niekolidującego z prawem) funkcjonowania w społeczeństwie po wyjściu na wolność. Pełnią wiele funkcji, między innymi są odpowiedzialni za:

- diagnozę sytuacji społeczno-ekonomicznej skazanych rozpoczynających odbywanie kary pod kątem określenia doświadczanych przez nich trudności życiowych, które mogły mieć wpływ na popełnione przestępstwa (na przykład uzależnienie, trudna sytuacja materialno-bytowa, zaburzenia behawioralne, seksualne), i wynikających z nich potrzeb;

- określanie kompetencji skazanych w celu doboru najbardziej efektywnych oddziaływań (z punktu widzenia pożądanych rezultatów pobytu w więzieniu) i ich dostosowania do indywidualnych zasobów każdego z nich (zob. też Ward, Willis 2016; Ward, Maruna 2007);

- pracę z jednostką z wykorzystaniem nowoczesnych zasad metodyki pracy socjalnej, zarządzanie przypadkiem z zastosowaniem mentoringu;

- prowadzenie mediacji między skazanymi a ich rodzinami albo osobami, które ucierpiały w wyniku popełnionych przez nich przestępstw;

- zapewnienie nadzoru klinicznego i stałego leczenia skazanym będącym w złej kondycji zdrowotnej (specjalistycznej opieki, leczenia psychiatrycznego dla więźniów cierpiących z powodu zaburzeń lub chorób psychicznych, oddziaływań terapeutycznych dla uzależnionych itd.);

- przeprowadzanie interwencji kryzysowej, jeżeli zachodzi taka potrzeba;

- usługi związane z planowaniem wyjścia na wolność i organizację pomocy na tym etapie, w tym kontakt $\mathrm{z}$ instytucjami zewnętrznymi (Gibelman 1995, za: Matejkowski i in. 2016).

System uwzględniający prowadzenie pracy socjalnej na terenie zakładów karnych zasadza się na założeniu, zgodnie z którym osoby skazane powinny opuszczać je jako lepiej przygotowane do funkcjonowania w społeczeństwie aniżeli w dniu, w którym rozpoczynają odbywanie kary (na przykład wprowadzona w 2000 roku w Szwecji zasada Bättreut - „Wychodzi lepszy” [Płatek 2007: 314]). Model ten uwzględnia nie 
tylko etap, w którym skazany wychodzi już na wolność - z tymi samymi zasobami, z którymi trafił do zakładu lub znacznie szczuplejszymi. „Uruchomienie” narzędzi pracy socjalnej już w momencie, gdy skazany trafia do więzienia, jest de facto formą działalności profilaktycznej. Ma na celu zapobieganie trudnościom, które towarzyszą niemałej grupie osób powracających do społeczeństwa po okresie izolacji. Jak wskazuje Stępniak,

(...) resocjalizacja skazanych odbywa się w zasadzie w ramach jednej instytucji (np. zakład karny), podczas pobytu w niej, praca socjalna zaś wychodzi na zewnątrz instytucji macierzystej (tj. więzienia), wykorzystując sieć instytucji środowiska lokalnego, do którego powraca skazany. Podejmują ją zatem w różnych odcinkach czasu inne jeszcze struktury, umożliwiając w ten sposób oddziaływanie permanentne, i to nie tylko na samego skazanego, lecz także na jego rodzinę, najbliższych, a nawet całe środowisko (2007: 166).

Warto w tym kontekście zauważyć, że zagadnienie pracy socjalnej na rzecz osadzonych pojawia się między innymi w materiałach dla słuchaczy szkoły podoficerskiej Centralnego Ośrodka Szkolenia Służby Więziennej:

\footnotetext{
Praca socjalna to uznana powszechnie działalność profesjonalna umożliwiająca jednostkom i rodzinom identyfikację osobistych, społecznych i tkwiących w środowisku trudności wpływających na nie niekorzystnie. Pracownik socjalny umożliwia im przezwyciężenie tych trudności poprzez działania podtrzymujące, rehabilitacyjne, zabezpieczające bądź korygujące. Aktualną tendencją do usprawnienia sposobu pomocy postpenitencjarnej jest wypracowanie modelu pracy socjalnej na rzecz osób przebywających w izolacji więziennej. Powinno to być zintegrowane działanie mające na celu przygotowanie skazanego na sytuację, którą zastanie w środowisku i przygotowanie środowiska do jego przyjęcia (Karczewski 2004, cyt. za: Pol 2011: 4).
}

Cytowany fragment pochodzi z 2004 roku. Zastanawiające jest, że do tej pory system resocjalizacyjny nie korzysta $\mathrm{z}$ takiej możliwości. W świetle prowadzonych zarówno w Polsce, jak i za granicą analiz mechanizmów wykluczania społecznego jednostek, grup, a nawet całych społeczności czy kategorii społecznych, jest to tendencja głęboko niepokojąca.

\section{Zakończenie}

Sposób definiowania resocjalizacji, jej istoty, celów i zadań determinuje repertuar oddziaływań dostępnych w więzieniu. Wśród nich próżno dziś szukać pracy socjalnej. Tym samym praca socjalna $\mathrm{z}$ osobami karanymi jest w Polsce de facto pracą $\mathrm{z}$ „eksskazanymi", to znaczy jest prowadzona wyłącznie po opuszczeniu placówki resocjalizacyjnej, o ile w ogóle. System resocjalizacyjny jest w tym czasie zdominowany przez tak zwany model korekcyjny, którego zdolności resocjalizacyjne są, paradoksalnie, 
coraz powszechniej uznawane za nieskuteczne: zarówno w perspektywie indywidualnych losów biograficznych skazanych, jak i makrostrukturalnej - ograniczania zjawiska recydywy.

Zdaniem Jana Dezyderiusza Pola (2011: 9) nieobecność pracowników socjalnych w systemie resocjalizacyjnym może po części wynikać z postrzegania tej profesji jako potencjalnej konkurencji czy zagrożenia dla pozycji kuratorów i wychowawców penitencjarnych lub obawy, że ich działania mogą wzajemnie na siebie nachodzić i dublować się. Kuratorzy sądowi i penitencjarni nie wykonują jednak pracy socjalnej. Co więcej, są oni bezpośrednio związani z wymiarem sprawiedliwości, co nie sprzyja budowie relacji zaufania i partnerstwa $z$ osobą karaną za popełnienie przestępstwa. Dlatego też idea wyszkolenia $i$,wkomponowania” pracowników socjalnych w system wykonywania kary pozbawienia wolności nie zakłada zastępowania nimi kuratorów czy wychowawców penitencjarnych, lecz raczej wspierania ich działalności, by zwiększyć efektywność oddziaływań resocjalizacyjnych. Stępniak zauważa, że „ewolucja sposobów zapobiegania przestępczości doprowadziła do tego, że obok elementu odpłaty w ramach kary zaczęto dostrzegać konieczność oddziaływań innego jeszcze rodzaju, alternatywnych w stosunku do represji" (2007: 167).

Prezentowany punkt widzenia jest $\mathrm{w}$ wielu treściach zbieżny $\mathrm{z}$ tendencjami liberalizacyjnymi w polityce karnej krajów Unii Europejskiej. Praca socjalna jest w tym ujęciu rozumiana jako integralny element systemu profilaktyki kryminalnej. Wykorzystanie jej bogatego dorobku w zakresie metodyki jest niewątpliwą szansą na uzupełnienie systemu resocjalizacji przestępców o treści do tej pory nieobecne lub zaniedbywane. Rzecz jasna, o ile przyjmiemy, że rolą resocjalizacji przestępców w Polsce jest nie tylko retrybucja (to jest odpłata za popełnienie przestępstwa) poprzez wykluczenie z życia społeczności i degradację statusu, lecz także społeczna reintegracja.

\section{Bibliografia}

Baldry E., McDonnell D., Maplestone P., Peeters M. (2006). Ex-prisoners, homelessness and the state in Australia. „Australian and New Zealand Journal of Criminology”, 39 (1): 20-33.

Bałandynowicz A. (2008). System probacji - prewencja, a nie represja, w: M. Lisiecki, M. Ruszkowska-Lipińska (red.), Zarzadzanie bezpieczeństwem w Unii Europejskiej wobec globalnych zagrożeń. Wydawnictwo Wyższej Szkoły Gospodarki Euroregionalnej, Józefów: 199-218.

Beckett Ch. (2010). Podstawy teorii dla praktyków pracy socjalnej, tłum M. Jasiński, B. Maliszewska. Wydawnictwo Akademii Pedagogiki Specjalnej, Warszawa.

Bradley T. (2005). Social exclusion, w: E. McLaughlin, J. Muncie (red.), The SAGE Dictionary of Criminology. SAGE Publications, London: 400-401.

Bronson J., Stroop J., Zimmer S., Berzofsky M. (2017). Drug Use, Dependence, and Abuse Among State Prisoners and Jail Inmates, 2007-2009. U.S. Department of Justice Office of Justice Programs, Bureau of Justice Statistics; https://www.bjs.gov/content/pub/pdf/dudaspji0709. pdf (dostęp: 15.02.2019). 
Chmielewska H. (2004). Psychologiczne aspekty izolacji, w: H. Chmielewska, K. Jędrzejak, T. Karczewski, P. Łapiński, B. Nowak, L. Stodolska, E. Szymczak (red.), Zagadnienia penitencjarne, Centralny Ośrodek Szkolenia Służby Więziennej, Kalisz: 165-221.

Ciosek M. (2003). Psychologia sadowa i penitencjarna, Wydawnictwo Naukowe PWN, Warszawa.

Czapska J., Szafrańska M., Wójcik D. (red.) (2016). Penalny populizm. Perspektywa polityczna i społeczna. Wydawnictwo Uniwersytetu Jagiellońskiego, Kraków.

Europejskie Centrum Monitorowania Narkotyków i Narkomanii (2017). Europejski raport narkotykowy 2017: Tendencje i osiagnięcia. Urząd Publikacji Unii Europejskiej, Luksemburg.

Fidelus A. (2012). Determinanty readaptacji społecznej skazanych. Wydawnictwo Uniwersytetu Kardynała Stefana Wyszyńskiego, Warszawa.

Filar M. (2014). Współczesne kultury penalne, w: M. Filar, J. Utrat-Milecki (red.), Kulturowe uwarunkowania polityki kryminalnej. Oficyna Naukowa, Warszawa: 43-54.

Friednship C., Blud L., Erikson M., Travers R. (2002). An evaluation of cognitive behavioral treatment for prisoners. „Findings”, 161; http://library.college.police.uk/docs/hofindings/ r161.pdf (dostęp: 24.09.2019).

Frieske K., Poławski P. (1996). Opieka i kontrola: instytucje wobec problemów społecznych. Śląsk, Katowice.

Goffman E. (1975). Charakterystyka instytucji totalnych, w: W. Dereczyński, A. Jasińska-Kania, J. Szacki (red.), Elementy teorii socjologicznych. PWN, Warszawa.

Goffman E. (2011). Instytucje totalne. O pacjentach szpitali psychiatrycznych i mieszkańcach innych instytucji totalnych, tłum. J. Łaszcz. Gdańskie Wydawnictwo Psychologiczne, Gdańsk.

Grabusińska Z. (2012). Rola pracy socjalnej w aktywnej integracji. Mazowieckie Centrum Polityki Społecznej, Warszawa.

Haney C. (2003). The psychological impact of incarceration. Implications for postprison adjustments, w: J. Travis, M. Waul (red.), Prisoners Once Removed: The Impact of Incarceration and Reentry on Children, Families and Communities. The Urban University Press, Washington: 76-92.

Hołda Z., Hołda J., Migdał J., Żórawska B. (2017). Prawo karne wykonawcze, wyd. 5. Wolters Kluwer Polska, Warszawa.

Hołyst B. (2007). Socjologia kryminalistyczna, t. 1. LexisNexis, Warszawa.

Houchin R. (2005). Social Exclusion and Imprisonment in Scotland. Glasgow Caledonian University, Glasgow.

Jaworska A. (2012). Leksykon resocjalizacji. Oficyna Wydawnicza „Impuls”, Kraków.

Kacprzak A. (2016). Kara pozbawienia wolności i jej (dys)funkcjonalność. Krytyka polskiej polityki karnej i resocjalizacyjnej w świecie akademickim. „Władza Sądzenia”, 10: 111-129.

Kacprzak A. (2017). Współczesne aspekty resocjalizacji przestępców w wybranych krajach europejskich. „Acta Universitatis Lodziensis: Folia Sociologica”, 62: 63-81.

Kacprzak A., Kudlińska I. (2014). Praca socjalna z osobami opuszczajacymi placówki resocjalizacyjne i ich rodzinami. Centrum Rozwoju Zasobów Ludzkich, Warszawa.

Kieszkowska A. (2012). Inkluzyjno-katalaktyczny model reintegracji skazanych. Konteksty resocjalizacyjne. Oficyna Wydawnicza „Impuls”, Kraków.

Kinner S.A. (2006). The Post-Release Experience of Prisoners in Queensland. Australian Institute of Criminology, Canberra. 
Klingemann J.I. (2012). Horyzonty zmiany zachowania nałogowego w Polsce. IPSiR UW, Warszawa.

Kornblum W., Julian J. (2012). Social Problems, wyd. 14. Pearson Education, Inc., London.

Lenczewska-Machel H., Machel H. (2009). Marginalizacja społeczna jako czynnik redukujący poprawcza sprawność więzienia, w: F. Kozaczuk (red.), Zagadnienia readaptacji społecznej skazanych. Wydawnictwo Uniwersytetu Rzeszowskiego, Rzeszów: 213-219.

Lindforss L, Magnusson D. (1997). Solution-focused therapy in prison. „Contemporary Family Therapy", 19 (1): 89-103.

Makowiecka D. (2008). Czy praca socjalna może być alternatywą dla pracy resocjalizacyjnej?, w: H. Malicka-Gorzelańczyk, P. Prusak (red.), W poszukiwaniu alternatywnych form i metod resocjalizacji skazanych. KPSW, Bydgoszcz: 86-96.

Matejkowski J., Johnson T., Severson M.E. (2016). Prison social work, w: Encyclopedia of Social Work. National Association of Social Workers, Oxford University Press, USA; https:// oxforde.com/social work/view/10.1093/acref ore/97801 (dostęp: 24.09.2019) .

Miller W., Rollnick S. (2010). Wywiad motywujacy. Jak przygotować ludzi do zmiany, tłum. A. Pokojska. Wydawnictwo Uniwersytetu Jagiellońskiego, Kraków.

Milner J., Jessop D. (2003). Domestic violence: Narrative and solutions, „Probation Journal”, 50 (2) : 127-141.

Miszewski K. (2015). Adaptacja do warunków więziennych skazanych długoterminowych, praca doktorska napisana pod kierunkiem prof. dra hab. Andrzeja Rzeplińskiego, Uniwersytet Warszawski.

Moore K.E., Stuewig J.B., Tangey J.P. (2016). The effects of stigma on criminal offenders functioning: A longitudinal medicational model. „Deviant Behavior”, 37 (2): 196-218.

Morenoff J.D., Harding D.J. (2014). Incarceration, prisoner reentry, and communities. „Annual Review of Sociology", 40: 411-429.

Motyka M. (2013). Dynamika zjawiska narkomanii: nowe populacje zażywających narkotyki. „Problemy Higieny Epidemiologicznej”, 94 (3): 435-445.

Mowen T.J., Visher C.A. (2013). Drug use and crime after incarceration: The role of family support and family conflict. „Justice Quarterly”. Published online, DOI: 10.1080/07418825.2013.77 1207.

Mumola C.J., Karberg J.C. (2006). Drug Use and Dependence, State and Federal Prisoners, 2004. U.S. Department of Justice Office of Justice Programs, Bureau of Justice Statistics; https:// www.bjs.gov/content/pub/pdf/dudsfp04.pdf (dostęp:15.02.2019).

Mumola C. (1999). Substance Abuse and Treatment. State and Federal Prisoners, 1997. Bureau of Justice Statistics Special Report, U.S. Department of Justice Office of Justice Programs; http://csdp.org/research/satsfp97.pdf (dostęp:15.02.2019).

Najwyższa Izba Kontroli (2015). Readaptacja społeczna skazanych na wieloletnie kary pozbawienia wolności. Informacja o wynikach kontroli, Departament Porządku i Bezpieczeństwa Wewnętrznego; https://www.nik.gov.pl/plik/id,9730,vp,12100.pdf (dostęp: 15.02.2019).

Nelson M., Deess P., Allen C. (1999). The First Month out. Post-Incarceration Experiences in New York City. Vara Institute of Justice, New York.

Newsome W.S. (2004). Solution-focused brief therapy group work with at-risk junior high school students: Enhancing the bottom line. „Research on Social Work Practice”, 14 (5): 336-343. 
Olech P. (2010). Strategie rozwiązywania problemu bezdomności w Stanach Zjednoczonych Ameryki, Australii i Europie, w: M. Dębski (red.), Problem bezdomności w Polsce. Wybrane aspekty. Diagnoza zespołu badawczego działajacego w ramach projektu „Gminny standard wychodzenia z bezdomności”, Standardy w Pomocy, Gdańsk: 168-221.

Phillips J. (2001). Cultural construction of manhood in prison. „Psychology of Men \& Masculinity", 2 (1):13-23.

Piechowicz M. (2012). Bezdomność jako problem społeczny i indywidualny - możliwości profilaktyki. „Resocjalizacja Polska”, 3: 327-340.

Płatek M. (2007). Systemy penitencjarne państw skandynawskich na tle polityki kryminalnej, karnej i penitencjarnej. Wydawnictwa Uniwersytetu Warszawskiego, Warszawa.

Poklek R. (2010). Instytucjonalne i psychospołeczne aspekty więzienia. Centralny Ośrodek Szkolenia Służby Więziennej, Kalisz.

Pol J.D. (2011). Praca socjalna w polityce i resocjalizacji penitencjarnej, w: T. Kamiński (red.), Politologia, polityka społeczna, praca socjalna. Wydawnictwo UKSW, Warszawa: 137-151.

Porozumienie z dnia 13 czerwca 2000 roku zawarte pomiędzy Ministerstwem Pracy i Polityki Społecznej a Centralnym Zarządem Służby Więziennej w sprawie zasad organizacji pomocy na rzecz osób zwalnianych z zakładów karnych i aresztów śledczych oraz rodzin osób pozbawionych wolności.

Przybyliński S. (2005). Podkultura więzienna. Wielowymiarowość rzeczywistości penitencjarnej. Oficyna Wydawnicza „Impuls”, Kraków.

Raine A. (2002). The biological basis of crime, w: J.Q. Wilson, J. Petersilia (red.), Crime: Public Policies for Crime Control. ICS Press, Oakland, CA: 43-74.

Raport z badań jakościowych na temat programu badawczo-szkoleniowego dotyczacego aktywizacji zawodowej i społecznej więźniów (2010). Projekt „Proces aktywizacji zawodowej i społecznej byłych więźniów”; http://www.zmiananalepsze.com.pl/Rapoort_badania_jakosciowe.pdf (dostęp: 15.02.2019).

Reiman J. (2001). The Rich Get Richer and the Poor Get Prison: Ideology, Class and Criminal Justice, 6 wyd., Allyn and Bacon, Boston MA.

Roczna informacja statystyczna za rok 2018 (2019). Centralny Zarząd Służby Więziennej, Warszawa; http://www.sw.gov.pl/strona/statystyka-roczna (dostęp: 15.02.2019).

Rzecznik Praw Obywatelskich (2017). Raport Rzecznika Praw Obywatelskich z działalności w Polsce Krajowego Mechanizmu Prewencji Tortur w roku 2016, „Biuletyn Rzecznika Praw Obywatelskich", nr 4, Biuro Rzecznika Praw Obywatelskich, Warszawa.

Social Exclusion Unit (2002). Reducing Re-offending by Ex-prisoners. Office of the Deputy Prime Minister, London.

Stępniak P. (1998). Wymiar sprawiedliwości i praca socjalna w krajach Europy Zachodniej. Ławica, Poznań.

Stępniak P. (2007). Praca socjalna w postępowaniu ze skazanymi. „Ruch Prawniczy, Ekonomiczny i Socjologiczny", LXIX (4): 159-173.

Stępniak P. (2017). Resocjalizacja (nie)urojona. O zawłaszczaniu przestrzeni penitencjarnej. Difin SA, Warszawa. 
Strategia Rozwoju Województwa Łódzkiego 2020. Zarząd Województwa Łódzkiego, Łódź; https:// rpo.lodzkie.pl/images/konkurs_2.3.1_cop_28122015/SRWL_2020.pdf (dostęp: 15.02.2019). Sytuacja osób opuszczających zakłady karne na terenie województwa łódzkiego (2012). Regionalne Centrum Polityki Społecznej w Łodzi; http://pokl-rcpslodz.pl/node/492 (dostęp: 15.02.2019). Szymanowska A. (2003). Więzienie i co dalej? Wydawnictwo Akademickie „Żak”, Warszawa. Szymanowska A. (2009). Czynniki utrudniające readaptację społeczna w świetle badań katamnestycznych, w: F. Kozaczuk (red.), Prawne i socjokulturowe uwarunkowania profilaktyki społecznej i resocjalizacji. Wydawnictwo Uniwersytetu Rzeszowskiego, Rzeszów: 285-301.

Szymanowska A., Korwin-Szymanowski G. (2009). Stosunek instytucji świadczacych pomoc do byłych skazanych, w: F. Kozaczuk (red.), Zagadnienia readaptacji społecznej skazanych. Wydawnictwo Uniwersytetu Rzeszowskiego, Rzeszów: 71-78.

The Role of Social Work in Juvenile Justice (2013). UNICEF, Switzerland.

The vicious circle of social exclusion and crime: Ireland's Disproportionate punishment of the poor (2012). Irish Penal Report Trust Position Paper, January 2012; http://www.iprt.ie/files/ Position_Paper_FINAL.pdf (dostęp:15.02.2019).

Travis J., Solomon A.L., Waul M. (2001). From Prison to Home. The Dimensions and Consequences of Prisoner Re-entry. Urban Institute Justice Policy Centre, Washington.

Trotter C. (1999). Working with Involuntary Clients. SAGE, London.

Uggen C., Manza J., Behrens A. (2011). 'Less than the average citizen': Stigma, role transition and the civic reintegration of convicted felons, w: S. Maruna, R. Immarigeon (red.), After Crime and Punishment. Pathways to Offender Reintegration. Routledge, London-New York. Ustawa o pomocy społecznej z dnia 1 stycznia 2004 roku (Dz.U. z 2004 r., Nr 64 poz. 593).

Ustawa z dnia 6 czerwca 1997 roku Kodeks karny wykonawczy (Dz.U. z 1997 r. Nr 90 poz. $557, \mathrm{z}$ późn. zm.).

Ustawa z dnia 9 kwietnia 2010 roku o Służbie Więziennej (Dz.U. z 2010 r. Nr 79 poz. 523).

Visher C.A. (2015). Re-entry and reintegration after incarceration, w: J. Wright (red.), International Encyclopedia of the Social \& Behavioral Sciences, wyd. 2, t. 20. Elsevier, Oxford: 61-66.

Wacquant L. (2009). Więzienia nędzy, tłum M. Kozłowski. Wydawnictwo Książka i Prasa, Warszawa.

Wacquant L. (2010). Prisoner reentry as myth and ceremony. „Dialectical Anthropology”, 34: 605-620.

Ward T., Maruna S. (2007). Rehabilitation. Beyond the Risk Paradigm. Routledge, London-New York.

Ward T., Willis G.M. (2016). Responsivity dynamic risk factors and offender rehabilitation: A comparison of the good lives model and the risk-need model, w: D.R. Laws, W. O'Donohue (red.), Treatment of Sex Offenders: Strengths and Weaknesses in Assessment and Intervention. Springer International Publishing, Cham, Switzerland: 175-190.

Western B., Pettit B. (2010). Incarceration \& social inequality. „Dædalus”, Summer, 139 (3): 8-19.

Zrewidowana Strategia Spójności Społecznej (2004). Europejski Komitet Spójności Społecznej, Rada Europy, Strasburg.

Żelazek J. (2003). Kara pozbawienia wolności w doświadczeniach więźniów. Próba sformułowania projektującej definicji kary pozbawienia wolności, w: J. Kwaśniewski (red.), Badania 
problemów społecznych, „Prace Katedry Socjologii Norm, Dewiacji i Kontroli Społecznej IPSIR UW", t. VI, Warszawa: 78-108. 